\title{
Strategi Pengembangan Desa Wisata di Wilayah Exit Jalan Tol Serang- Panimbang
}

\author{
Ari Ekoprianto, Myrza Rahmanita, Himawan Brahmantyo \\ Sekolah Tinggi Pariwisata Trisakti \\ Email corresponding author: ${ }^{1}$ ariekoprianto@gmail.com
}

\begin{abstract}
ABSTRAK
Pembangunan jalan tol dapat memacu pertumbuhan perekonomian di suatu tempat, salah satunya dengan jalan mempermudah akses bagi pariwisata yang merupakan salah satu syarat dari sebuah destinasi wisata. Jalan tol menuju Panimbang, dimana KEK Tanjung Lesung berada. Di sepanjang jalan tol desa wisata yang dekat letaknya dengan eksit tol yaitu desa wisata Sukaratu di Kecamatan Cikeusal. Penelitian ini bermaksud mengungkap potensi pariwisata dan strategi pengembangan yang dapat digunakan untuk membangun desa tersebut menjadi salah satu destinasi di sepanjang tol Jakarta-Panimbang. Metode yang digunakan adalah kualitatif deskriptif dengan pengambilan data melalui wawancara, observasi dan dokumentasi, serta studi literatur, dengan menggunakan sebanyak 8 (delapan) informan. Hasil penelitian menunjukkan bahwa Sukaratu memiliki potensi untuk berkembang diantaranya karena aksesibilitas, amenitas dan etraksi sudah tersedia. Sedangkan analisis SWOT menunjukkan bahwa terlepas dari unsur aksesibilitas, amenitas dan atraksi yang sudah ada, potensi yang ada belum digali secara maksimal dan untuk itu sumber daya manusia pengelola dan pelaku usaha masih harus ditingkatkan. Selain itu Sukaratu juga menghadapi ancaman persaingan dari desa wisata sejenis dan karenanya perlu melakukan diversifikasi dan inovasi agar produk pariwisata dan ekraf di dalamnya tetap memiliki kekhasan.
\end{abstract}

Kata Kunci: Analisis SWOT, Desa Wisata, Jalan Tol, Pengembangan, Sukaratu

\section{PENDAHULUAN}

Provinsi Banten memiliki banyak tempat wisata yang menarik minat wisatawan untuk mengunjunginya, namun dibalik keindahan Provinsi Banten yang banyak tempat wisatanya wilayah ini masih terkendala dalam infrastrukturnya. Kondisi jalan yang rusak yang menjadi penghambat wisatawan mengunjungi destinasi wisata di Provinsi Banten.

Tabel 1. Data Kunjungan Wisatawan Ke Provinsi Banten 2018

\begin{tabular}{|l|l|l|l|}
\hline No & Kabupaten / Kota & Wisatawan Nusantara & Wisatawan Mancangera \\
\hline 1 & Kabupaten Pandeglang & 3.102 .472 & 2.579 \\
\hline 2 & Kabupaten Lebak & 680.102 & 357 \\
\hline 3 & Kabupaten Tangerang & 74.085 & 28.212 \\
\hline 4 & Kabupaten Serang & 8.392 .828 & 1.470 \\
\hline 5 & Kota Tangerang & 1.277 .760 & 237.996 \\
\hline 6 & Kota Cilegon & 866.772 & 46.182 \\
\hline 7 & Kota Serang & 2.208 .570 & 1.215 \\
\hline 8 & Kota Tangerang Selatan & 1.379 .551 & 8.992 \\
\hline
\end{tabular}

Sumber: Dinas Pariwisata Provinsi Banten, 2018 
Berdasarkan Tabel diatas dapat dilihat bahwa Kabupaten Serang dan Kota Serang merupakan daerah tertinggi untuk kedatangan wisatawan nusantara. Sedangkan, Kota Tangerang merupakan daerah tertinggi untuk kedatangan wisatawan mancanegara. Melihat data tersebut maka dapat disimpulkan bahwa daya tarik wisata yang terdapat di Kota Serang dan Kabupaten Serang memiliki daya tarik tersendiri bagi setiap wisatawan yang berkunjung. 10 destinasi prioritas yang ditetapkan oleh Kementerian Pariwisata dan Ekonomi Kreatif menjadikan Tanjung Lesung yang terdapat di Kabupaten Pandeglang, Kecamatan Panimbang, Banten menjadi Kawasan Ekonomi Khusus (KEK). Tanjung Lesung merupakan KEK Pariwisata pertama dan telah diresmikan beroperasi pada Februari 2015. KEK Tanjung Lesung memiliki letak yang strategis dan akses yang mudah dijangkau, yaitu $170 \mathrm{~km}$ dari Ibukota Jakarta dan dapat ditempuh melalui perjalanan darat selama 2,5 - 3 jam. Berasal dari kata "lesung" yaitu alat penumbuk padi tradisional, Tanjung Lesung memiliki bentuk dataran pantai wilayah yang menjorok ke laut dan mirip lesung.

Dengan adanya kawasan Tanjung Lesung tersebut maka pemerintah pun melakukan inisiatif untuk pendongkrakan ekonomi daerah sekitar dalam sektor pariwisata. Hal pertama yang dilakukan pemerintah yaitu memperbaiki infrastruktur yang saat ini sudah ada dan juga melakukan revitalisasi wilayah tersebut. Dalam hal ini, pemerintah pun membangun jalan tol sebagai alternatif bagi wisatawan yang datang berkunjung agar pariwisata di daerah tersebut mengalami peningkatan yang signifikan.

Pembangunan jalan tol Serang - Panimbang sepanjang 83,6 km bertujuan untuk menyediakan akses ke Kawasan Ekonomi Khusus (KEK) Tanjung Lesung dan Taman Nasional Ujung Kulon. Proyek direncanakan akan terdiri dari tiga seksi: Seksi I Serang Rangkasbitung; Seksi II Rangkasbitung - Bojong; dan Seksi III Bojong - Panimbang. Jika tidak ada aral melintang, Tol Serang-Panimbang (Serpan) sesi I sepanjang 26 kilometer, diprediksikan akan segera beroperasi pertengahan tahun 2021 (https: kppip.go.id diakses tanggal 7 Januari 2021). Penyelenggaraan jalan tol dimaksudkan untuk mewujudkan pemerataan pembangunan dan hasil-hasilnya serta keseimbangan dalam pengembangan wilayah dengan memperhatikan keadilan, yang dapat dicapai dengan membina jaringan jalan yang dananya berasal dari pengguna jalan, dan bertujuan meningkatkan efisiensi pelayanan jasa distribusi guna menunjang peningkatan pertumbuhan ekonomi terutama di wilayah yang sudah tinggi tingkat perkembangannya. (Peraturan Pemerintah Republik Indonesia nomor 15 tahun 2005 tentang Jalan Tol). Pembangunan jalan tol ini, dinilai strategis karena menghubungkan Kota Serang dan tiga kabupaten sekaligus yaitu Kabupaten Serang, Kabupaten Lebak dan Kabupaten Pandeglang. Melibatkan 14 (empat belas) Kecamatan, dan 50 (lima puluh) Desa di Kota Serang, Kabupaten Serang, Kabupaten Lebak dan Kabupaten Pandeglang di Provinsi Banten. Ruas Tol Serang-Panimbang ini dibangun diluar jalur pariwisata konvensional yang telah ada selama ini dikembangkan di Provinsi Banten dan pembangunan desa wisata adalah salah satu strategi yang dapat dilaksanakan untuk menggerakkan perekonomian yang langsung dirasakan oleh masyarakat di wilayah yang dilalui jalan tol Serang-Panimbang (Sunaryo, 2013). 


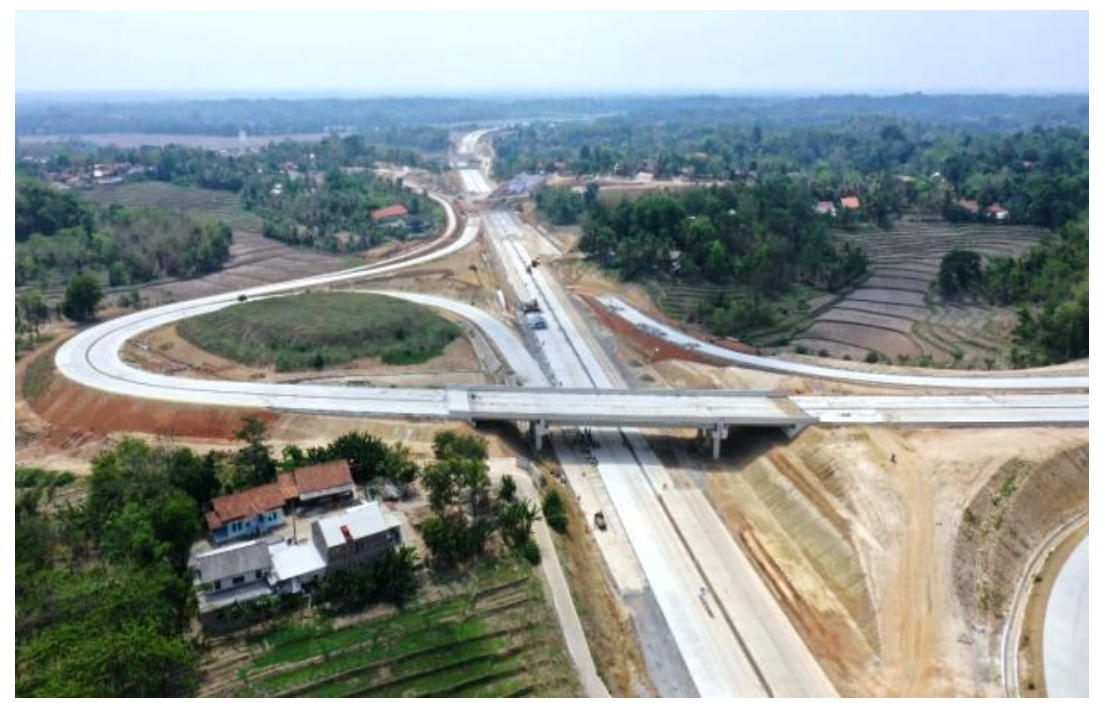

Gambar 1. Jalan Tol Serang - Panimbang Sumber: Detik Finance, 2020

Saat ini, disekitar pembangunan jalan tol tersebut terdapat salah satu desa yang sudah ditetapkan melalui Surat Keputusan Bupati Serang Nomor 556/Kep.969Huk.Disporapar/2019 menjadi desa wisata yaitu Desa Sukaratu yang terletak di Kecamatan Cikeusal, Kabupaten Serang yang saat ini berkembang menjadi salah satu destinasi wisata yang dapat dijadikan pilihan diantara destinasi lainnya yang ada di Provinsi Banten. Desa Sukaratu, merupakan kawasan pedesaan yang masih sangat alami serta banyak memiliki potensi wisata di dalamnya. Desa ini juga terletak di dekat exit toll Cikeusal sehingga dengan adanya tol Serang - Panimbang diharapkan dapat meningkatkan perekonomian warga sekitar dan juga meningkatkan kesejahteraan masyarakat lokal.

\section{Landasan Teori}

Desa wisata adalah suatu bentuk integrasi antara atraksi, akomodasi dan fasilitas pendukung yang disajikan dalam suatu struktur kehidupan masyarakat yang menyatu dengan tata cara dan tradisi yang berlaku (Nuryati, Wiendu, 1993) Desa Wisata didefinisikan sebagai sebagian atau keseluruhan wilayah desa yang dimiliki potensi, produk dan aktivitas wisata yang dapat dimanfaatkan untuk pengembangan pariwisata dan dikelola oleh kelompok masyarakat di desa secara berkelanjutan (Ida Bagus Suryawan, 2015; Nofiyanti, 2018) yang komponen pembentuknya terdiri atas wilayah, produk, organisasi, sarana prasarana, wisatawan, dan jejaring sosial. Menurut Cooper (2013) sebuah destinasi wisata selain memiliki kompenen wisata juga harus memiliki 3A yang diantaranya aksesibilitas (accessibility), amenitas (amenity), dan atraksi (attraction) sehingga pengembangan wisata di suatu destinasi dapat berjalan optimal dan dipertimbangkan secara matang oleh stakeholder terkait. Komponen desa wisata diharuskan pula terdapat Sesuatu yang dapat dilakukan (Something to do), Sesuatu yang dapat dibeli (Something to buy), dan Sesuatu yang dapat dilihat (Something to see) (Yoeti, 2005).

Menurut Kamus Besar Bahasa Indonesia, potensi adalah kemampuan yang mempunyai kemungkinan dikembangkan. Sedangkan, potensi wisata adalah berbagai sumber daya baik itu berupa suasana, peristiwa, benda maupun layanan/jasa yang dimiliki oleh suatu tempat dan dapat dimanfaatkan sebagai unsur dalam pengembangan kepariwisataan. Berbagai 
sumber daya tersebut dapat mengembangkan suatu daerah menjadi atraksi wisata (tourist attraction) yang dimanfaatkan untuk kepentingan ekonomi dengan tetap memperhatikan aspek-aspek lainnya (Pendit, 2003). Potensi wisata dapat diidentifikasi dengan melihat potensi internal dan potensi eksternal. Potensi internal objek wisata adalah potensi wisata yang terdapat pada suatu objek itu sendiri yang meliputi komponen kondisi fisik objek, kualitas objek, dan dukungan bagi pengembangan. Potensi eksternal objek wisata adalah potensi wisata yang mendukung pengembangan suatu objek wisata yang terdiri dari aksesibilitas, fasilitas penunjang, dan fasilitas pelengkap. Maka dapat disimpulkan bahwa potensi wisata adalah kemampuan suatu daerah atau wilayah dalam mengembangkan berbagai sumber daya menjadi atraksi wisata (tourist attraction).

\section{METODE PENELITIAN}

Penelitian ini menggunakan metode penelitian deskriptif dengan pendekatan kualitatif. Penelitian deskriptif merupakan penelitian yang dimaksudkan untuk mengumpulkan informasi mengenai status suatu gejala yang ada, yaitu keadaan gejala menurut apa adanya pada saat penelitian dilakukan (Arikunto, 2005). Penelitian kualitatif dilakukan karena peneliti ingin mengeksplor fenomena-fenomena yang tidak dapat dikuantifikasikan yang bersifat deskriptif seperti pengertian tentang suatu konsep yang beragam, gambar-gambar, tata cara suatu budaya dan lain sebagainya (Komariah \& Satori, 2011) Purposive sampling adalah penentuan sampel dengan pertimbangan tertentu.

Tabel 2. Sampel Penelitian Desa Sukaratu

Teknik Sampling

Anggota Dewan

Kepala Daerah

Purposive Sampling

Sumber: Olahan Peneliti, 2021

\section{Informan}

Anggota Dewan

Kepala Desa Sukaratu

Kadispar / Sekdis

Kadis/Sekdis

Kepala Bumdes

Anggota Pokdarwis

Di dalam teknik pengumpulan data, peneliti menggunakan teknik pengumpulan data triangulasi yaitu teknik pengumpulan data yang bersifat menggabungkan dari berbagai teknik pengumpulan data dan sumber data (Sugiyono, 2012) dan terdiri dari observasi, wawancara dan studi literatur. Kemudian teknik analisis yang digunakan merupakan kualitatif, sehingga metode dalam penelitian ini menggunakan metode IFAS dan metode EFAS, dan matriks SWOT tujuannya yaitu untuk meneliti lingkungan faktor internal yaitu kelebihan dan kelemahan, dan lingkungan faktor eksternal yaitu peluang dan ancaman di Desa Wisata Sukaratu (Rangkuti, 2017).

\section{HASIL DAN PEMBAHASAN}

\section{Potensi dan Strategi Pengembangan Pariwisata di Desa Sukaratu}

Keseluruhan potensi wisata yang terdapat di Desa Sukaratu tentunya dapat dikembangkan menjadi sesuatu yang dapat dijadikan daya tarik wisata bagi wisatawan nusantara maupun mancanegara nantinya. Sesuatu yang mempunya nilai daya tarik wisata tentunya akan menarik minat wisatawan untuk berkunjung kembali dan tentunya hal tersebut akan 
berdampak positif pada kelangsungan hidup masyarakat lokal di Desa Sukaratu.

Selain potensi wisata, maka strategi pengembangan untuk menjadikan Desa Sukaratu sebagai desa wisata yang menerapkan nilai-nilai pariwisata berkelanjutan juga menjadi sesuatu yang sangat penting bagi kelangsungan kegiatan pariwisata di Desa Sukaratu nantinya. Hal ini dapat dilihat dari adanya peran komunitas lokal dalam menjadi penggerak pariwisata di Desa Sukaratu seperti menjadi pemandu wisata, penjual makanan dan minuman, penjual cendramata, hingga pemilik homestay. Selain itu, berdasarkan hasil wawancara bersama beberapa pemangku kepentingan terpilih (POKDARWIS, Kepala Desa, dan Kepala Bidang Destinasi DISPORPAR Kabupaten Serang, Kepala BUMDES, dan anggota DPRD Kabupaten Serang) maka dapat ditentukan bahwa terdapat strategi wisata di Desa Sukaratu yang dapat dilihat dari attraction, accesbilitity, amenity, dan ancillary. Oleh karena itu, di Desa Wisata Sukaratu saat ini telah memiliki atraksi wisata sebagai strategi utama pariwisata di Desa Wisata Sukaratu seperti aktivitas wisata alam yang dapat dilakukan di Desa Sukaratu. Hal ini dikarenakan, Desa Sukaratu mewarisi tradisi dan budaya Banten yang bercorak agraris.

Dewasa ini Desa Sukaratu telah terbangun ruang terbuka hijau berupa taman desa bernama Taman Mahkota Ratu yang menampilkan konsep ethnic dan agroculture dengan sumbangan Rp 16.263.000,-untuk pendapatan asli desa (PADes) Pembangunan Taman Mahkota Ratu secara sengaja ditujukan untuk mengurangi stigma negatif pada lahan pertanian karena sebagian besar warga Desa Sukaratu menggantungkan hidup dari sektor pertanian, namun tak sedikit generasi muda yang melihat dunia pertanian sebagai sektor yang ketinggalan zaman. Oleh karena itu Sekrataris Desa Sukaratu, Bapak Sukron mengusung revitalisasi pertanian dan budaya Banten melalui Musyawarah Desa yang dilakukan sejak tahun 2016 yang memutuskan pembangunan ruang publik yang memiliki nilai edukasi dan estetika yang tinggi. Pembagian keuntungan kerjasama itu terbagi dengan pola $40 \%$ untuk pengurus, $10 \%$ untuk PADes, 27\% untuk BUMDes, 11\% untuk Kas BUMDes, 5\% untuk CSR dan 2-5\% untuk pemilik lahan.

Pembangunan Taman Mahkota Ratu dimulai pada 2016 dengan pembiayaan dari APBDesa 2016 dan dana swadaya (gotong-royong). Selanjutnya, BUMDes Sukamaju mendapat kewenangan untuk pengelolaan taman desa dengan penyertaan modal dari Dana Desa sejumlah Rp 50.000.000,- Desa Sukaratu sendiri memiliki Saung Tani Pos Penyuluhan Desa (POSLUHDES) yang representatif untuk tempat pertemuan, musyawarah, pembinaan, serta pelatihan pertanian di area Taman Mahkota Ratu. Secara rutin, Taman Mahkota Ratu menjadi ruang untuk; (1) musyawarah kelembagaan desa (PKK, Karang Taruna, RT dan RW); (2) musyawarah terkait pertanian, (3) musyawarah lainnya ang bersifat umum atau insidentil. Pengunjung Taman Mahkota Ratu datang dari berbagai daerah, seperti Cilegon, Tangerang, Pandeglang, dan juga dari DKI Jakarta. Sebagian besar pengunjung adalah anakanak muda yang menyukai swafoto (selfie). Kreativitas Pemerintah Desa Sukaratu, Kecamatan Cikeusal dengan membangun Taman Mahkota Ratu menjadi contoh bagi daerah lainnya di Indonesia. Kolaborasi antarpihak dan integrasi pertanian-wisata dapat meningkatkan pembangunan desa dan pertanian yang tangguh. Pada 2017, Desa Sukaratu meraih Juara 1 dalam kategori Desa Ketahanan Pangan di Provinsi Banten.

Untuk melakukan analisis potensi dan strategi pengembangan desa wisata di wilayah Exit Jalan Tol Serang - Panimbang maka peneliti telah menetapkan variabel penelitian yang telah disesuaikan dengan teori yang peneliti gunakan di bab sebelumnya. Maka berdasarkan data di lapangan, maka ditemukan data sebagaimana ada di tabel 3.

Sedangkan di Desa Sukaratu ini juga terdapat potensi internal dimana potensi ini sudah ada dan dapat dikembangkan agar menjadi sebuah strategi dalam pengembangan 
pariwisata di Desa Sukaratu. Potensi secara internal ini berupa; kondisi fisik objek, kualitas objek, dukungan bagi pengembangan. Oleh karena itu, berdasarkan data temuan di lapangan maka ditemukan data sebagai berikut.

Tabel 3. Potensi Eksternal di Desa Sukaratu

\begin{tabular}{|c|c|c|}
\hline No & Variabel & Indikator \\
\hline 1 & Accesibility & $\begin{array}{l}\text { 1. Jarak dari kota menuju desa wisata } \\
\text { 2. } \text { Lokasi yang mudah dijangkau } \\
\text { 3. } \\
\text { Sarana transportasi }\end{array}$ \\
\hline 2 & Atrractions & $\begin{array}{ll}\text { 1. Aktifitas seni dan budaya tradisional } \\
\text { masyarakat } \\
\text { 2. Hutan lindung, beberapa flora dan fauna } \\
\text { yang masih terjaga } \\
\text { 3. Kerajinan tangan masyarakat Desa Wisata } \\
\text { Sukaratu }\end{array}$ \\
\hline 3 & Amenities & $\begin{array}{l}\text { 1. Tersedianya homestay } \\
\text { 2. Tersedianya toko souvenir } \\
\text { 3. Dekat dengan Pusat Kesehatan Masyarakat, } \\
\text { pos polisi, ATM }\end{array}$ \\
\hline
\end{tabular}

Sumber: Olahan Peneliti, 2021

\begin{tabular}{|c|c|c|}
\hline No & Variabel & Indikator \\
\hline 1 & $\begin{array}{c}\text { Kondisi Fisik } \\
\text { Objek }\end{array}$ & $\begin{array}{l}\text { 1. Kebiasaan-kebiasaan penduduk dalam menjaga desa } \\
\text { 2. Keramahtamahan masyarakat } \\
\text { 3. Adat istiadat yang masih kental }\end{array}$ \\
\hline 2 & $\begin{array}{c}\text { Kualitas Objek } \\
\text { Wisata }\end{array}$ & $\begin{array}{l}\text { 1. Masih mempertahankan tradisi yang ada sejak } \\
\text { zaman dahulu } \\
\text { 2. Lokasi desa yang sejuk dikarenakan dikelilingi oleh } \\
\text { area pertanian } \\
\text { 3. Masyarakat memahami bagaimana menjadi } \\
\text { penggerak pariwisata di Desa Wisata Sukaratu } \\
\text { sehingga regulasi pun dibuat dengan baik agar dapat } \\
\text { dipahami wisatawan yang berkunjung }\end{array}$ \\
\hline 3 & $\begin{array}{l}\text { Dukungan } \\
\text { Bagi } \\
\text { Pengembangan }\end{array}$ & $\begin{array}{l}\text { 1. Kenyamanan wisatawan dalam berkunjung ke Desa } \\
\text { Wisata Sukaratu } \\
\text { 2. Ancaman berupa investor asing yang masuk ke } \\
\text { Desa Sukaratu } \\
\text { 3. Ancaman SDM yang belum bisa ikut dalam } \\
\text { mengelola Desa Wisata Sukaratu dan keterbatasan } \\
\text { bahasa }\end{array}$ \\
\hline
\end{tabular}


Berdasarkan data di lapangan diatas maka peneliti juga melakukan analisis SWOT terkait potensi dan strategi pengembangan pariwisata berkelanjutan di Desa Wisata Sukaratu yang dapat dilihat pada pembahasan selanjutnya.

\section{Analisis SWOT Desa Sukaratu}

Hasil dari wawancara kepada 3 responden terpilih yaitu Sekretaris Desa Sukaratu, Pengelola Taman Mahkota Ratu, dan Kabid Destinasi DISPPORPAR Kabupaten Serang yang dianggap mempunyai peran dalam mengambil keputusan strategi pada pengembangan, memperoleh penilaian dari setiap indikator internal menentukan kekuatan dan kelemahan, lalu untuk indikator-indikator eksternal akan menentukan peluang serta ancaman. Hal tersebut bergantung kepada besarnya nilai yang diberikan.

Berdasarkan kekuatan yang dimiliki oleh Desa Wisata Sukaratu ialah jarak dari kota menuju desa wisata, lokasi yang mudah dijangkau, aktifitas seni dan budaya tradisional masyarakat, hutan lindung yang masih terjaga, organisasi, pemerintah daerah tersedianya homestay, dan merupakan salah satu desa yang terletak di kawasan pembangunan Exit Jalan Tol Serang - Panimbangan. Sedangkan untuk kelemahan yang dimiliki Desa Wisata Sukaratu adalah sarana transportasi dan kondisi aksesbilitas yang masih minim. Hasil ini di dapatkan berdasarkan wawancara yang dilakukan oleh 3 orang responden yang dipilih dan mengetahui jelas mengenai Desa Wisata Sukaratu. Hasil pada setiap indikator merupakan rata-rata hasil triangulasi dari 3 responden.

Hasil wawancara juga menunjukkan bahwa peluang dan ancaman Desa Wisata Sukaratu terdapat 3 responden yang menilai. Peluang yang ada di Desa Wisata Sukaratu yaitu kebiasaan-kebiasaan penduduk dalam menjaga desa dan hutan, keramahtamahan masyarakat, adat istiadat yang masih terjaga, peraturan adat Desa Wisata Sukaratu dan peraturan pemerintah, peluang usaha bagi masyarakat, lapangan pekerjaan bagi masyarakat dan kenyamanan wisatawan. Sedangkan untuk ancaman bagi Desa Wisata Sukaratu berupa tempat wisata yang sejenis, ancaman berupa investor asing yang masuk ke Desa Sukaratu tanpa sepengetahuan pengelola dan ancaman SDM yang belum bisa ikut dalam mengelola Desa Wisata Sukaratu. Rating yang dilakukan oleh 3 responden ditentukan dan dianggap memenuhi kriteria. Rating dari indikator-indikator ini ialah rata-rata dari rating 3 responden dengan menjumlahkan rating pada indikator-indikator eksternal lalu dibagi dengan seluruh jumlah responden untuk mendapatkan rating di masing-masing indikator eksternal. Analisa SWOT dapat dilihat pada tabel 4 dibawah ini :

Tabel 5. Analisa SWOT di Desa Sukaratu

\begin{tabular}{|l|l|l|}
\hline IFAS & $\begin{array}{l}\text { KEKUATAN (S) } \\
\text { 1. Jarak dari kota menuju desa } \\
\text { wisata }\end{array}$ & $\begin{array}{l}\text { KELEMAHAN (W) } \\
\text { 1. Sarana transportasi } \\
\text { 2. Kerajinan tangan } \\
\text { 2. Lasasi yang mudah } \\
\text { dijangkau }\end{array}$ \\
3. Aktifitas seni dan budaya \\
4. Hutan lindung, flora dan \\
fauna \\
5. Organisasi dan masyarakat \\
6. Pemerintah daerah
\end{tabular}




\begin{tabular}{|c|c|c|}
\hline & $\begin{array}{ll}\text { 7. } & \text { Homestay } \\
\text { 8. } & \text { Berada di wilayah Exit Jalan } \\
\text { Tol Serang-Panimbang }\end{array}$ & \\
\hline $\begin{array}{l}\text { PELUANG }(\mathbf{O}) \\
\text { 1. Kebiasaan-kebiasaan } \\
\text { penduduk } \\
\text { 2. Keramahtamahan } \\
\text { masyarakat } \\
\text { 3. Adat istiadat } \\
\text { 4. Peraturan adat dan peraturan } \\
\text { pemerintah } \\
\text { 5. Peluang usaha bagi } \\
\text { masyarakat } \\
\text { 6. Lapangan pekerjaan } \\
\text { 7. Kenyamanan wisatawan }\end{array}$ & $\begin{array}{l}\text { STRATEGI (SO) } \\
\text { 1. Meningkatkan aktifitas seni } \\
\text { dan budaya Desa Wisata } \\
\text { Sukaratu. } \\
\text { 2. Meningkatkan kesadaran } \\
\text { dalam menjaga lingkungan } \\
\text { desa dan hutan. }\end{array}$ & $\begin{array}{l}\text { STRATEGI (WO) } \\
\text { 1. Memberikan sarana } \\
\text { transportasi kepada } \\
\text { wisatawan yang } \\
\text { datang } \\
\text { 2. Mendukung } \\
\text { kerajinan tangan } \\
\text { yang dihasilkan } \\
\text { masyarakat. }\end{array}$ \\
\hline $\begin{array}{l}\text { ANCAMAN (T) } \\
\text { 1. Tempat wisata yang sejenis } \\
\text { 2. Ancaman investor asing } \\
\text { yang masuk ke wilayah desa } \\
\text { Sukaratu } \\
\text { 3. Ancaman SDM yang belum } \\
\text { bisa ikut mengelola Desa } \\
\text { Wisata Sukaratu }\end{array}$ & $\begin{array}{l}\text { STRATEGI (ST) } \\
\text { 1. Memberikan himbauan } \\
\text { hingga aturan mengenai Desa } \\
\text { Wisata Sukaratu } \\
\text { 2. Melakukan promosi Desa } \\
\text { Wisata Sukaratu }\end{array}$ & $\begin{array}{l}\text { STRATEGI (WT) } \\
\text { 1. Menyediakan local } \\
\text { guide } \\
\text { 2. Membuka pelatihan } \\
\text { bagi masyarakat }\end{array}$ \\
\hline
\end{tabular}

Sumber: Olahan Peneliti, 2021

Berdasarkan hasil analisis SWOT yang dilakukan peneliti di Desa Sukaratu, maka peneliti juga melakukan pembahasan terhadap hasil analisis SWOT dan juga studi dokumentasi dan observasi yang dilakukan oleh peneliti di lapangan, sebagaia berikut:

\section{Strategi SO (Kekuatan, Peluang)}

1. Meningkatkan aktifitas seni dan budaya masyarakat Desa Wisata Sukaratu sehingga wisatawan tertarik untuk berkunjung.

2. Meningkatkan kesadaran dalam menjaga lingkungan desa dan hutan berupa beberapa aturan adat desa dan aturan pemerintah agar masyarakat serta wisatawan dapat memperhatikan hal tersebut.

\section{Strategi WO (Kelemahan, Peluang)}

1. Sarana transportasi bagi wisatawan baik melalui transportasi umum dan kendaraan pribadi (motor dan mobil).

2. Memberi dukungan kepada masyarakat Desa Wisata Sukaratu untuk kerajinan tangan yang dibuat dengan mempromosikan dan membuka tempat untuk menjual hasil tangan masyarakat ke wisatawan. 


\section{Strategi ST (Kekuatan, Ancaman)}

1. Memberi himbauan dan aturan mengenai Desa Wisata Sukaratu agar wisatawan dapat memperhatikan aktifitas yang dapat dilakukan selama berkunjung.

2. Mempromosikan Desa Wisata Sukaratu melalui social media dan informasi kepada masyarakat secara langsung. Hal ini dilakukan agar masyarakat luas mengetahui obyek wisata yang mereka ingin kunjungi.

\section{Strategi WT (Kelemahan, Ancaman)}

Desa Wisata Sukaratu menyediakan local guide agar mempermudah wisatawan untuk datang berkunjung dan melakukan beberapa aktifitas yang diperbolehkan. Membuka pelatihan bagi masyarakat Desa Wisata Sukaratu akan kesadaran dalam pengelolaan desa wisata sebagai obyek wisata.

Apabila suatu desa wisata dikelola dengan baik maka kegiatan pariwisata di desa tersebut pun nantinya dapat berjalan secara optimal sehingga masyarakat lokal pun merasakan dampak positif adanya kegiatan pariwisata di Desa Sukaratu. Berdasarkan pada Analisa SWOT diatas dapat dilihat bahwa posisi Desa Sukaratu saat ini memiliki kekuatan yang memang sudah ada di desa tersebut. Namun, peluang dan ancaman pun terdapat di Desa Sukaratu antara lain peluang Desa Sukaratu untuk menjadi salah satu desa wisata yang optimal dapat dikembangkan dikarenakan Desa Sukaratu terletak di kawasan pembangunan Exit Jalan Tol Serang-Panimbang. Seiring berjalannya kegiatan pariwisata di Desa Sukaratu maka ancaman pun dapat dirasakan nantinya antara lain terdapat desa wisata sejenis yang sama-sama menawarkan atraksi dan aktivitas wisata yang sama dikarenakan potensi alam yang memang sejenis di wilayah Provinsi Banten.

Namun, hal ini dapat diminimalisirkan apabila masyarakat lokal terus bekerja sama dengan stakeholder terkait untuk mengelola dan terus mengembangkan segala potensi wisata yang ada di Desa Sukaratu. Inovasi pembangunan wisata juga terus dikembangkan agar Desa Sukaratu tidak ketinggalan zaman namun tetap mempertahankan segala otentisitas dan orisinalitas yang sudah ada sebelum adanya kegiatan pariwisata di Desa Sukaratu. Keterbatasan pengetahuan masyarakat lokal terkait sektor pariwisata juga dapat terus ditingkatkan dengan cara memberikan pelatihan terkait pengelolaan sektor pariwisata yang diberikan oleh stakeholder terkait.

\section{KESIMPULAN DAN SARAN}

\section{Kesimpulan}

Beberapa poin mengenai potensi dan strategi pengembangan pariwisata berkelanjutan di Desa Wisata Sukaratu yaitu sebagai berikut:

1. Potensi Desa Wisata Sukaratu ialah jarak dari kota menuju desa wisata, lokasi yang mudah dijangkau, aktifitas seni dan budaya tradisional masyarakat, hutan lindung yang masih terjaga, organisasi pemerintah daerah yang mendukung, tersedianya homestay, dan merupakan salah satu desa yang terletak di kawasan pembangunan Exit Jalan Tol Serang - Panimbangan sehingga memungkinkan untuk lebih mudah menarik wisatawan yang memang melintas ke wilayah tersebut. Yang masih menjadi kekurangan adalah kesulitan angkutan umum dan belum adanya paket wisata yang dapat menahan wisatawan selama mungkin yang kemungkinan disebabkan belum maksimalnya pengeksploran potensi di desa wisata tersebut. Walaupun ketersediaan angkutan umum masih bermasalah, tetapi hal itu bukanlah sesuatu yang dibutuhkan wisatawan 
pengguna jalan tol yang membawa kendaraan pribadi. Adapun tantangan yang adalah bermunculannya desa wisata sejenis yang akan menggunakan sistem ATM (amati, tiru, modifikasi) namun hal ini dapat diatasi dengan terus mengembangkan inovase dan diversifikasi produk pariwisata dan ekraf yang menjadi ciri khas Sukaratu, dan untuk itu sumber daya manusia di Sukaratu, baik pengelola maupun pelaku wisatanya, harus terus ditingkatkan.

2. Strategi yang hendaknya diterapkan untuk membangun Sukaratu adalah dengan memperbaiki kondisi di dalam yaitu terus menggali potensi yang ada dan terus memberikan peningkatan keterampilan kepada para pelaku usaha di desa serta secara maksimal menggali semua potensi yang ada karena jumlah dan keragaman potensi tersebut lah yang akan menentukan berapa lama wisatawan dapat ditahan untuk tinggal. Tidak lupa, pembenahan secara organisasi dan admnistrasi juga perlu dilakukan agar kegiatan wisata dan pencatatnnya dapat dilakukan dengan tertib. Sementara ke luar, pihak pengelola harus lebih giat mempromosikan keberadaan Desa Wisata Sukaratu. Hal ini dapat dilakukan melalui media social dan tentu saja dengan dukungan dan Kerjasama dari pemerintah dan pengelola jalan tol.

\section{Saran}

Saran dalam strategi pengembangan Desa Wisata Sukaratu yaitu sebagai berikut:

1, Terus mengeksplore kekayaan budaya dan alam sehingga bukan hanya menghasilkan produk yang telah biasa ada, akan tetapi juga melakukan berbagai inovasi sehingga produk yang ada bisa dimodifikasi. Hal ini akan menciptakan produk unggulan yang unik dan berbeda dengan desa-desa wisata sejenis yang ada di sekeliling dan mungkin saja menjadi pesaing.

2. Memberikan pelatihan dan pendampingan kepada para pelaku wisata dan ekraf local yang tujuannya agak kapasitas mereka bertambah sehingga dapat menawarkan produk yang berkualitas prima dengan pelayanan yang prima terhadap wisatawan. Pelatihan dan pendampingan ini tentu saja harus dilakukan dengan menggandeng pihak-pihak dalam pentahelix pariwisata, dan untuk pembiayaan bisa juga memanfaatkan dana CSR yang biasa diberikan perusahaan swasta, pemerintah dan daerah. Untuk dapat memaksimalkan potensi dan mengembangkannya, sumber daya manusia menjadi yang utama yang harus ditingkatkan.

\section{DAFTAR PUSTAKA}

Arikunto, (2015) Prosedur Penelitian: Suatu Pendekatan Praktik. Rineka Cipta,. Jakarta.

A.Yoeti, Oka. (2005). Perencanaan Strategi Pemasaran Daerah Tujuan Wisata.

Jakarta: PT. Pradnya Paramita.

Cooper, Fketcher, J., Gilbert, D., \& Wanhill, S. (2013). Tourism, Principles and

Prantice. London: Logman.

Freddy Rangkuti. (2017) Analisis SWOT. Jakarta : PT Gramedia Pustaka Utama.

Komariah\& Satori. (2011). Metode Penelitian Kualitatif. Bandung. Alfabeta.

Nofiyanti, F., Sulartiningrum, S., \& Fitriana, R. (2018). Pelatihan Peningkatan Kualitas SDM

Bidang Pariwisata di Desa Wisata Cikolelet Serang Banten. Jurnal SOLMA, 7(2), 176181.

Nuryanti, Wiendu. (1993). Concept, Perspective and Challenges, makalah bagian dari

Laporan Konferensi. Internasional mengenai Pariwisata Budaya.

Pearce. Douglas, G. (1981). Tourist Development, London: Longman 
Pendit, Nyoman S. (2003). Pengantar Ilmu Pariwisata. Jakarta: Pradnya Paramita

Poerwadarminta W.J.S. 1976. Kamus Umum Bahasa Indonesia, Jakarta: Balai Pustaka

Pambudy, A. P., \& Syairozi, M. I. (2019). Analisis Peran Belanja Modal dan Investasi Swasta Terhadap Pertumbuhan Ekonomi Serta Dampaknya Pada Kesejahteraan Masyarakat. Jurnal Ekonomi dan Bisnis, 20(1), 26-39.

Sugiyono. 2012. Metode Penelitian Kuantitatif Kualitatif dan R\&B. Bandung: Alfabeta.

Sunaryo, Bambang (2013) Kebijakan Pembangunan Destinasi Pariwisata : Konsep dan Aplikasinya di Indonesia. Penerbit Gava Media

Suryawan, Ida Bagus. (2015). Perkembangan dan Pengembangan

DesaWisata.Depok: Herya Media. 